\title{
Using Juxtaposing Pictures in Improving Descriptive Writing Skill of the Second Year Students of SMAN 3 Enrekang
}

\author{
Rahmad Risan \\ Universitas Negeri Makassar, \\ Hasriani G. \\ Indonesia \\ Universitas Negeri Makassar, \\ rahmadrisan@unm.ac.id \\ Indonesia
}

\begin{abstract}
The objective of the research was to find out whether or not the use of juxtaposing pictures can improve the students' writing ability especially in writing description. The researchers applied a pre-experimental method with one group pre-test and one group post-test design. The subject of the research was the second year students of SMAN 3 Enrekang in academic year 2017-2018.

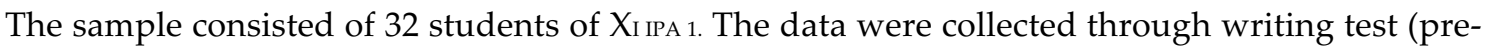
test and post-test). To find out the effectiveness of juxtaposing pictures in improving writing ability, the researcher applied t-test analysis. The result of the analysis showed that there was a significant difference between pre-test and post-test. The value of t-test (9.09) was greater than the t-table (2.039) and degree of freedom $(\mathrm{df})=31$. It is concluded that juxtaposing pictures is effective in improving the students' writing ability in writing description.
\end{abstract}

\section{INTRODUCTION}

Writing is an English skill defined as how to express ideas on a paper to form words, words to sentences, sentences to paragraph. The ideas of writing may be from the writer's feeling, opinion, or may come from prior knowledge such as: result of reading book, discussion or hear and watching TV. Things that we see can affect our thinking and view especially in writing because everything what we want to write depends on our thought. So, before we write, we need to determine what we write and also the writer should have something meaningful to convey. Mostly people have difficulties when they want to write something, may be lack of ideas, feeling bad, or may be lack of vocabulary. Sometimes we lose of opinion and we only can write a little. It seems that ideas become important part in constructing writing. Beside it, in speaking we can use many ways of communication such as facial expression or body language but differently in writing we just use words to convey information. Keeping in our mind about choice of words, grammatical structure, length of sentences, and organizing way so that the reader will receive the messages we intend to convey. We have to arrange the words based on topic clearly in order to make its meaning readable, understandable in order the readers can get the meaning easily.

Based on some of the difficulties in writing, the researchers tried to use juxtaposing pictures as a medium in learning because it has enormous potential as learning tools. In using juxtaposing pictures the writers can see, look, and enjoy the pictures. So, it can make the students be able to imagine what they want to write. And these juxtaposing pictures not only illustrate a topic but also can contribute to the context in which the language is being used and motivate students. Pictures represent something in providing information that can help students to continue general idea and describe it easily. It can enhance students to develop their selfesteem in teaching and learning activities of the written language. It makes the lesson more dynamic as imagination are aroused and as a source of discovery. This is especially 
useful with those students who find it difficult to use their imagination.

The picture provides a support and ideas which the students can then build on more easily than invent their own story all together. The Old saying that picture is a worth of thousands of words, means that it can raise the production of words and a multitude of creative and analytical thoughts. But other researcher found out that the juxtaposing pictures can improve writing skill just in vocabulary side. There is no significant improvement in grammar, mechanics, content, and organization. So, the researcher tried to limit the skill of writing just in writing description.

Referring to the statements above, the researchers tried to study about the improvement of descriptive writing skill by using pictures specifically juxtaposing pictures. Juxtaposing represents our tendencies in perceiving something which compares a numbers of pictures that placed side by side. For these reasons, the researchers took the title "Using Juxtaposing Pictures in Improving Descriptive Writing Skill of the Second Year Students of SMAN 3 Enrekang in academic year 2017-2018". This research aimed to find out whether or not the use of juxtaposing pictures significantly improves the students' ability in writing description. The researchers hoped this research would be useful and give contribution for foreign language teaching as consideration to use pictures as a tool of stimulation and to enhance students' attention for more exploring ideas especially in teaching writing. The scope of the study was limited to improvement for descriptive writing skill of students through juxtaposing pictures. It focused on five criteria or five components of good writing namely content, mechanics, organization, language use, and vocabulary. The study was located in SMA N 3 Enrekang.

\section{LITERATURE REVIEW}

Behrens, et al. (1999) define writing as a process or an activity to mark letter or number on paper so, the people can read it. Different from Behrens, Kroma (1988, p.30) and Byrne (2001, p. 77) in Nurbaya defined writing is expression of the writer's idea by producing graphic symbols to form words, words to sentences, sentences to paragraph on the paper so the reader can follow what the writer means. Byrne in same line adds that the most important one in writing is how to make the communication successful that is should be readable and understandable to the reader.

\section{a. Forms of Writing}

Wishon and Burks (1980, pp. 378-383) divide forms of writing into four divisions namely narration, description, exposition and argumentation.

1) Narration

Narration is the form of writing used to relate the story of acts or events. It places occurrences in time and tells what happened according to natural time sequences. Types of narration include short stories, novels, and new stories, as well as large part of our everyday social interchange in the form of letters and conversation.

2) Description

Description reproduces the way things look, smell, taste, feel, or sound. It may also evoke moods, such as happiness, loneliness, or fear. It is used to create a visual image of people, places, even of units of time-days, times of day, or seasons. It may be used also to describe more than the outward appearance of people. It may tell about their traits of character or personality.

3) Exposition

Exposition is used in giving information, making explanations, and interpreting meanings. It includes editorials; essay, and informative and instructional material. Used in combination with narrative, exposition supports and illustrates. Used apart from narrative, it 
stands alone as an essay. Used alone or with narrative, exposition may be developed in a number of ways as follows: (a) Process. Exposition may be used to explain a process that is to tell how something is made or done. (b) Definition. An explanation of what a word or a term means is another kind of exposition. The simplest form is a statement and this applies to dictionary definitions. (c) Analysis. It divides a subject into parts and examines those parts. (d) Criticism. It involves evaluation, which is analyzing and weighing strengths and weaknesses.

\section{4) Argumentation}

Argumentation is used in persuading and convincing. It is closely related to exposition and it is often found combined with it. The aim is to make a case or to prove or disprove a statement or proposition. It may present arguments to persuade the reader to accept an idea or a point of view.

\section{b. Concept of Descriptive Writing Skill}

1) Definition of descriptive writing

Some experts had defined descriptive writing, sometimes, people might think that descriptive writing strives to invoke a vivid and involved experience for the reader. Actually, descriptive writing skill can mean much more. According to Rita Putatunda (2010), (in buzzle.com), means that Descriptive writing is about using the power of words to arouse and capture the reader's attention and create a lasting impact.

From Wikipedia, the free encyclopedia defines that more than any other kind of writing, descriptive writing strives to invoke a vivid and involved experience for the reader. It is often considered as one of the most creative forms of writing since it is basically about being able to evoke emotions in the reader through the power of words. A good descriptive essay, for instance, has the ability to arouse the reader's senses and create a lasting impact on his or her mind.
This effect can be achieved not through statistics and facts, but by detailed descriptions and observations. As you start with your descriptive writing, one of the most important things is identifying exactly what you are setting out to describe. Usually, a descriptive writing will include the depiction of the following: a place, a person, a pet, an object, an experience, or a memory. Anything that you experience or perceive about your subject can be the point of your descriptive writing.

\section{2) The component of writing}

The good writing skill can be analyzed to group and varied skills. Heaton (1988:135) divided components writing into five main areas. They are grammar, mechanics, vocabulary, content and organization.

\section{a) Grammar}

Grammar concerns about the ability to write correct and appropriate sentences. The writer has to give attention for preposition, tenses such as using of verbs, nouns, adjective, also conjunction and articles. It is very important to the writer to clarify the correct usage of point grammar because reader will be difficult to understand it. It has a great influence so, we have to reread and review what we have written.

b) Mechanics

It is related with the ability to use correctly words to the written language such as using of capitalization, punctuation, spelling. It is very important to lead the readers to understand or recognize what the writer means to express. The use of favorable mechanics in writing will make the readers easy to the group to conveying ideas or message of writing. The explanation as follows: a) capitalization, the use of capitalization can clarify the ideas. If the sentences are not capitalized correctly, ambiguity and misunderstanding will appear. It also helps to differentiate from sentences to others. 
The words which are capitalized at beginning of: the name of people, organization, first and last word of title. b) Punctuation. Punctuation can help the readers to identify should be taken as a unit of meaning and suggest how the units of it relate to each other. c) Spelling. Using of spelling has three rules; they are suffixes addition, plural formation and the change of certain words.

\section{c) Content}

The content of writing is about the ability to think creatively and develop thoughts, excluding all irrelevant information. It should be clear to the readers. So, they can understand what the messages convey and gain information from it. Also, the content of writing should be well unity and complete because the characteristic of good writing has unity and completeness.

d) Vocabulary

Vocabulary is an essential part of compose writing. The writes need vocabulary mastery well to express or write their ideas. The effective using of words or vocabulary in writing must be relevant with the topic to let the readers perceive and feel it. Someone who lack of vocabulary will be difficult to compose what they are going to express but appropriate words will help writers to compose writing.

\section{e) Organization}

Organization is the ability to develop ideas and topic which relevant in a united form. On the other hand, it concern in ways of writer to arrange and organize the ideas or messages in writing. There are many ways in process of organization writing involves coherence, order of importance, general to specific, specific to general, chronological order and spatial pattern.

\section{c. Juxtaposing Pictures}

Sometimes students need an opportunity to investigate a subject, or an opportunity to express their feelings about a subject rather than a challenge. For this reason, juxtaposing picture as one of the visual learning materials that very suitable to use in language teaching because students are encouraged to express feelings and ideas and to exchange experiences while little or no emphasis is placed on whether it was right or wrong. The researcher decided to use this kind of pictures and it was introduced by Wright.

The Free Dictionary (2000) sited that juxtaposing is placed side by side often for comparison or contrast. Whether Wright (2005) described that it's displaying number of pictures which have different aspect of topic. By juxtaposing their different qualities of pictures are highlighted. Students are motivated to express their ideas based on picture then they will stimulate to compare some of advantages of the picture that they choose. In this way, the other pictures can give ideas and rethink again what we will write. The kind of paragraph which developed is description. Even though it was not real description but the students should give their reasons and explanation clearly.

The lostpedia, lost encyclopedia sited that in literature and film, juxtaposing is the arrangement of two opposing ideas, characters, objects, etc. side-by-side or in similar narratives for effect. Lost often uses juxtaposition to further develop the storyline or characters - it is applied variously to opposing emotions, abstract concepts, character traits/values, or images.

\section{METHODOLOGY}

This research used a pre-experimental method. It investigated the effect of using juxtaposing pictures in improving descriptive writing skill of the students. The design of this research used one group pretest-posttest design. The group did the pretest (O1), the treatment $(\mathrm{X})$, and did the posttest $(\mathrm{O} 2)$. The comparison of the pretest and posttest cores 
determines the success of the treatment. The design can be described as follows.

\begin{tabular}{|lcc|}
\hline Pretest & Treatment & Posttest \\
O1 & $x$ & O2 \\
& & $($ Gay, 2006:252) \\
\hline
\end{tabular}

The population in this research was the second year students of SMA N 3 Enrekang academic year 2017-2018. The research used cluster random sampling technique. One of the eight classes, i.e. class XI IPA1 was taken as the sample. The students' number of the class was 32 students. The researcher used writing test as instrument, pretest and posttest. The students wrote a paragraph according to the title given. Test was used to measure students' descriptive writing skill. The data from the students was calculated in writing ability. The five components of good writing can be seen from the content, organization, vocabulary, language use or grammar and mechanics.

\section{FINDINGS AND DISCUSSION}

\section{The Students' Writing Ability in Pre-test and Post-test}

The students' score of pre-test and posttest were observed based on five components of writing. The data can be seen in Table 1. the mean score to find out the students'

Table 1. Frequency and Rate Percentage of the Students' Writing Ability on Content Component

\begin{tabular}{|l|c|l|c|c|c|c|}
\hline \multirow{2}{*}{ No } & \multirow{2}{*}{ Score } & \multirow{2}{*}{ Category } & \multicolumn{2}{|c|}{ Pre-test } & \multicolumn{2}{c|}{ Post-test } \\
\cline { 4 - 7 } & & & Frequency & Percentage & Frequency & percentage \\
\hline 1 & $27-30$ & Very Good & - & - & - & - \\
\hline 2 & $23-26$ & Good & 4 & $12.5 \%$ & 8 & $25 \%$ \\
\hline 3 & $20-22$ & Average & 10 & $31.25 \%$ & 18 & $56.25 \%$ \\
\hline 4 & $17-19$ & Poor & 18 & $56.25 \%$ & 6 & $18.75 \%$ \\
\hline 5 & $13-16$ & Very poor & - & - & - & - \\
\hline & TOTAL & & 32 & 100 & 32 & 100 \\
\hline
\end{tabular}

Table 1 shows that in the pre-test, none of the students who was classified into Very Poor score, 18 students or $56.25 \%$ were classified into Poor score, 10 students or $31.25 \%$ were classified into Average score, 4 students or $12.5 \%$ were classified into Good score, and none of them was classified into Very Good score.
The table above also shows the result of students writing ability in content component in posttest. None of the students was classified into Very Poor score, 6 students or $18.75 \%$ were classified into Poor score, 18 students or $56.25 \%$ were classified into Average score, 8 students or $25 \%$ were classified into Good score, and none of them was classified into Very Good score.

Table 2. Frequency and Rate Percentage of the Students' Writing Ability on Vocabulary Component

\begin{tabular}{|c|c|l|c|c|c|c|}
\hline \multirow{2}{*}{ No } & \multirow{2}{*}{ Score } & \multirow{2}{*}{ Category } & \multicolumn{2}{|c|}{ Pre-test } & \multicolumn{2}{c|}{ Post-test } \\
\cline { 4 - 7 } & & & Frequency & Percentage & Frequency & percentage \\
\hline 1 & $18-20$ & Very Good & - & - & 1 & $3.12 \%$ \\
\hline 2 & $15-17$ & Good & 5 & $15.62 \%$ & 9 & $28.12 \%$ \\
\hline 3 & $12-14$ & Average & 15 & $46.87 \%$ & 18 & $56.25 \%$ \\
\hline 4 & $9-11$ & Poor & 12 & $37.5 \%$ & 4 & $12.5 \%$ \\
\hline 5 & $5-8$ & Very poor & - & - & - & - \\
\hline
\end{tabular}




\begin{tabular}{|l|l|l|l|l|l|l|}
\hline & TOTAL & & 32 & 100 & 32 & 100 \\
\hline
\end{tabular}

Table 2 shows that in the pre-test, 12 students or $37.5 \%$ were classified into Poor score, 15 students or $46.87 \%$ were classified into Average score, 5 students or $15.62 \%$ were classified into Good score, and none of them was classified into Very Good and Very Poor score.
Table 2 also shows the result of students' writing ability in vocabulary component in post-test. It shows that 4 students or $12.5 \%$ were classified into Poor score, 18 students or $56.25 \%$ were classified into Average score, 9 students or $28.12 \%$ were classified into Good score, 1 student or $3.12 \%$ was classified into Very Good score. and none of them was classified into Very Poor score.

Table 3 Frequency and Rate Percentage of the Students' Writing Ability on Organization Component

\begin{tabular}{|c|c|l|c|c|c|c|}
\hline \multirow{2}{*}{ No } & \multirow{2}{*}{ Score } & \multirow{2}{*}{ Category } & \multicolumn{2}{|c|}{ Pre-test } & \multicolumn{2}{c|}{ Post-test } \\
\cline { 4 - 7 } & & & Frequency & Percentage & Frequency & percentage \\
\hline 1 & $18-20$ & Very Good & - & - & - & - \\
\hline 2 & $15-17$ & Good & 2 & $6.25 \%$ & 4 & $12.5 \%$ \\
\hline 3 & $12-14$ & Average & 20 & $62.5 \%$ & 24 & $75 \%$ \\
\hline 4 & $9-11$ & Poor & 10 & $31.25 \%$ & 4 & $12.5 \%$ \\
\hline 5 & $5-8$ & Very poor & - & - & - & - \\
\hline & TOTAL & & 32 & 100 & 32 & 100 \\
\hline
\end{tabular}

Table 3 shows that in the pre-test, there are 10 students or $31.25 \%$ who were classified into Poor score, 20 students or $62.5 \%$ were classified into Average score, 2 students or $6.25 \%$ were classified into Good score, and none of them was classified into Very Poor and Very Good score.

The table above also shows the result of students' writing ability in organization component in post-test. There are 4 students or $12.5 \%$ who were classified into Poor score, 24 students or $75 \%$ were classified into Average score, 4 students or $12.5 \%$ were classified into Good score, and none of them was classified into Very Poor and Very Good score.

Table 4. Frequency and Rate Percentage of the Students' Writing Ability on Language Use Component

\begin{tabular}{|c|c|l|c|c|c|c|}
\hline \multirow{2}{*}{ No } & \multirow{2}{*}{ Score } & \multirow{2}{*}{ Category } & \multicolumn{2}{|c|}{ Pre-test } & \multicolumn{2}{c|}{ Post-test } \\
\cline { 4 - 7 } & & & Frequency & Percentage & Frequency & percentage \\
\hline 1 & $23-25$ & Very Good & - & - & - & - \\
\hline 2 & $20-22$ & Good & 2 & $6.25 \%$ & 3 & $9.37 \%$ \\
\hline 3 & $16-19$ & Average & 14 & $43.75 \%$ & 23 & $71.87 \%$ \\
\hline 4 & $9-15$ & Poor & 16 & $50 \%$ & 6 & $18.75 \%$ \\
\hline 5 & $5-8$ & Very poor & - & - & - & - \\
\hline & TOTAL & & 32 & 100 & 32 & 100 \\
\hline
\end{tabular}

Table 4 shows that in the pre-test, there are 16 students or $50 \%$ who were classified into Poor score, 14 students or $43.75 \%$ were classified into Average score, 2 students or 6.25 $\%$ were classified into Good score, and none of them was classified into Very Good and Very Poor score.
Table 4 also shows the result of students' writing ability in language use component in post-test. There are 6 students or $18.75 \%$ who were classified into Poor score, 23 students or $71.87 \%$ were classified into Average score, 3 students or $9.37 \%$ were classified into Good score, and none of them was classified into Very Good and Very Poor score. 
Table 5. Frequency and Rate Percentage of the Students' Writing Ability on Mechanics Component

\begin{tabular}{|c|c|l|c|c|c|c|}
\hline \multirow{2}{*}{ No } & \multirow{2}{*}{ Score } & \multirow{2}{*}{ Category } & \multicolumn{2}{|c|}{ Pre-test } & \multicolumn{2}{c|}{ Post-test } \\
\cline { 4 - 7 } & & & Frequency & Percentage & Frequency & percentage \\
\hline 1 & 5 & Very Good & - & - & - & - \\
\hline 2 & 4 & Good & 1 & $3.12 \%$ & 12 & $37.5 \%$ \\
\hline 3 & 3 & Average & 8 & $25 \%$ & 17 & $53.12 \%$ \\
\hline 4 & 2 & Poor & 23 & $71.87 \%$ & 3 & $9.37 \%$ \\
\hline 5 & 1 & Very poor & - & - & - & - \\
\hline & TOTAL & & 32 & 100 & 32 & 100 \\
\hline
\end{tabular}

Table 5 shows that in the pre-test, there are 23 students or $71.87 \%$ who were classified into Poor score, 8 students or $25 \%$ were classified into Average score, 1 student or $3.12 \%$ was classified into Good score, and none of them was classified into Very Good and Very Poor score.
Table 5 also shows the result of students' writing ability in content component in posttest. There are 3 students or $9.37 \%$ who were classified into Poor score, 17 students or $53.12 \%$ were classified into Average score, 12 students or $37.5 \%$ were classified into Good score, and none of them was classified into Very Good and Very Poor s

Table 6 Frequency and Rate Percentage of the Students' Writing Ability on Five components

\begin{tabular}{|l|c|l|c|c|c|c|}
\hline \multirow{2}{*}{ No } & \multirow{2}{*}{ Score } & \multirow{2}{*}{ Category } & \multicolumn{2}{|c|}{ Pre-test } & \multicolumn{2}{c|}{ Post-test } \\
\cline { 4 - 7 } & & & Frequency & Percentage & Frequency & Percentage \\
\hline 1 & $100-88$ & Very Good & - & - & - & - \\
\hline 2 & $87-75$ & Good & 3 & $9.37 \%$ & 5 & $15.62 \%$ \\
\hline 3 & $74-64$ & Average & 8 & $25 \%$ & 15 & $46.87 \%$ \\
\hline 4 & $63-45$ & Poor & 21 & $65.62 \%$ & 12 & $37.5 \%$ \\
\hline 5 & $44-34$ & Very Poor & - & - & - & - \\
\hline \multicolumn{2}{|c}{ TOTAL } & 32 & 100 & 32 & 100 \\
\hline
\end{tabular}

Table 6 for pre-test shows that there were 21 students or $65.25 \%$ who were classified into Poor, 8 students or $25 \%$ were classified into Average, 3 students or $9.37 \%$ were classified into Good, and none of them was classified into Very Good and Very Poor.

Table 6 also shows the result of students' writing ability in content component in posttest. There are 12 students or $37.5 \%$ who were

classified into Poor, 15 students or $46.87 \%$ were classified into Average, 5 students or $15.62 \%$ and none of them was classified into Very Good and Very Poor.

\section{The Mean Score and Standard Deviation}

The following table shows the distribution of mean score and standard deviation in pre-test and post-test.

Table 7 The Mean Score and Standard Deviation of the Student's Pre-test and Post-test

\begin{tabular}{|l|c|c|c|c|}
\hline \multirow{2}{*}{ Components } & \multicolumn{2}{|c|}{ Pre-test } & \multicolumn{2}{c|}{ Post-test } \\
\cline { 2 - 5 } & Mean Score & $\begin{array}{c}\text { Standard } \\
\text { Deviation }\end{array}$ & Mean Score & $\begin{array}{c}\text { Standard } \\
\text { Deviation }\end{array}$ \\
\hline Content & 19.40 & 2.19 & 20.96 & 2.28 \\
\hline Vocabulary & 12.28 & 2 & 13.34 & 1.94 \\
\hline Organization & 12.06 & 1.46 & 12.90 & 1.53 \\
\hline Language use & 15.03 & 2.42 & 16.34 & 2.12 \\
\hline Mechanics & 2,31 & 0.54 & 3.28 & 0.63 \\
\hline Final Score & 61.06 & 7.47 & 66.81 & 6.82 \\
\hline
\end{tabular}


The result of data analysis from pre-test and post-test of the students' writing ability in terms of content component is shown in the table above. The mean score in pre-test is 19.40 (categorized as poor) and the standard deviation is 2.19. In contrary the mean score of post-test is 20.96 (categorized as average) with the standard deviation is 2.28 .

The result of data analysis from pre-test and post-test of the students' writing ability in terms of vocabulary component shows that the mean score in the pre-test is 12.28 (categorized as average) and the standard deviation is 2. The mean score of post-test is 13.34 (categorized as average) with the standard deviation is 1.94

The result of data analysis from pre-test and post-test of the students' writing ability in terms of organization component shows that the mean score in the pre-test is $\mathbf{1 2 . 0 6}$ (categorized as average) and the standard deviation is 1.46. The mean score of post-test is 12.90 (categorized as average) with the standard deviation is 1.53.

The result of data analysis from pre-test and post-test of the students' writing ability in terms of language use component shows that the mean score in the pre-test is 15.03 (categorized as poor) and the standard deviation is 2.42. The mean score of post-test

Table 8. The t-test of the Students' Improvement is 16.34 (categorized as average) with the standard deviation is 2.12 .

The result of data analysis from pre-test and post-test of the students' writing ability in terms of mechanics component shows that the mean score in the pre-test is 2.31 (categorized as poor) and the standard deviation is 0.54 . The mean score of post-test is 3.28 (categorized as average) with the standard deviation is 0.63 .

From the result of five components above, the final score from pre-test and posttest of the students' writing ability shows that the mean score in the pre-test is 61.06 (categorized as poor) and the standard deviation is 7.47. The mean score of post-test is 66.81 (categorized as average) with the standard deviation is 6.82

\section{Test of Significance}

To know the level of significance of the pre-test and post-test, the researcher used ttest analysis on the level of significance $(p)=$ 0.05 with the degree of freedom $(\mathrm{df})=\mathrm{N}-$ 1 ,where $\mathrm{N}=$ number of subject (32 students) then the value of $t$-table is 2.045 . The $t$-test statistical, analysis for independent sample was applied. The following table shows the result of t-test calculation:

\begin{tabular}{|c|c|c|}
\hline Components & t-test value & t-table value \\
\hline Content & 7.09 & 2.045 \\
\hline Vocabulary & 4.95 & 2.045 \\
\hline Organization & 4.94 & 2.045 \\
\hline Language use & 4.27 & 2.045 \\
\hline Mechanics & 9.7 & 2.045 \\
\hline Final Score & 10.49 & 2.045 \\
\hline
\end{tabular}

Table 8 shows that $t$-test value for content is greater than $\mathrm{t}$-table $(7.09>2.045), \mathrm{t}$ test value of vocabulary is greater than $t$-table $(4.95>2.045)$, t-test value of organization is greater than t-table $(4.94>2.045)$, t-test value of language use is greater than $t$-table $(4.27>2.045)$, t-test value of mechanics is greater than $t$-table $(9.7>2.045)$, the final result shows that t-test value for the final score of students' ${ }^{\prime}$ writing ability $10.49>t$-table $=2.045$. It means that there is significant difference between the students' writing skill before and after using juxtaposing pictures in writing description of the second year students of SMA N 3 Enrekang. It is also said that the 
null hypothesis $\left(\mathrm{H}_{0}\right)$ is rejected and the alternative hypothesis $\left(\mathrm{H}_{1}\right)$ is accepted.

The discussion of this research is described based on the findings above. Before the treatment, the writing ability of the students was very low. This condition might be caused by teaching method and less writing process, so that the students could not improve their writing achievement. It can be seen in table 6 that the students' writing achievement on pretest was very poor. Based on the findings, scores of posttest was greater than those in pretest. In the first meeting, the researchers actually found that most students did not know about descriptive writing. They got problem in five components namely content, vocabulary, organization, language use, and mechanic. Generally, most of the students were still low in writing description.

In the second meeting until the last, students tried to pay attention and participate in using juxtaposing pictures. At the end of each the meeting, the researcher used to ask the students to write descriptive using juxtaposing pictures at least six sentences.

After the treatment, students' achievement increased. In terms of the content, in pretest, students were lack of ideas to explore their thought to form sentences that related to the topic, most of supporting ideas were not related to the topic and the way to describe the topic was not specific so the content was misunderstood. But after the treatment, students' achievement improved. Juxtaposing pictures helped the students to find words by seeing the picture and imagine what the picture could give to their ideas. That is why the students got the highest scores in content of writing component. This is similar with Ebel and Frisbie, (1985:85) that if the topic is too popular, the students might have read or heard a lot about that topic, so that they do not have to think how to express the ideas about the topic, they will only need to recall and then write what they have read and heard a lot. it means content is higher than the others.
In addition to the content, the next problem was the lack of vocabulary before treatment. Most of the students could not write vocabulary perfectly. Moreover students could not translate their words in English, so that their description was not very detail and did not use very specific character. Students just described the topic simply and generally. When the researcher walked near the students, most of them asked questions about vocabulary. After the treatment, students' achievement improved. The researcher gave chance to the students to find a lot of vocabularies related to the topic. So they also know what kind of vocabulary they want to use related to the topic in the picture. This is similar to Andi Niar Rezky's research that concluded that writing skill of the fourth semester students of English department improved using juxtaposing pictures. After treatment using juxtaposing pictures the score improved just in vocabulary side and also similar with Jacobs et al. (1981), in his study, he found that variable of vocabulary had the highest contribution to the total writing variance. This highest contribution might be related to the learning experiences of the subject in their home countries where the instructional emphasis is on formal properties of language.

This also influenced the content and organization part because students could not express their thought if they did not have a number of vocabularies. They also have difficulties to organize words well because most of the words found in dictionary and this consumed time. In this case students got the second lower of contribution scores. This is almost similar to Weir (1990) who found that component of organization had the lowest amount of contribution to the overall writing variance.

The next important problems faced by the students were language use and mechanics. The students had less understanding of English grammar because it has very different pattern from Indonesia language. So, writing activities were also directed to improve grammatical problems 
writing simple sentences focusing on the word order. Researcher tried to explain much grammatical especially those are related directly to descriptive paragraph, such as present tense. In pretest, many students did not know what tense that suited in descriptive writing so that their writing was misunderstood. Therefore, researcher explained present tense in each meeting. This is different with Astika (1993) who found that the students indicate the highest contribution of grammar and the lower contribution of organization.

Mechanic component score of posttest was greater than pretest. In pretest, students was less attention in writing correctly such as using capitalization, punctuation, and spelling. Although the students wrote a lot of words or many vocabularies. They found it difficult to write correctly. It caused the students' writing was not easy to understand and recognize what the writer means to express. After knowing about mechanic or in another hand, after the treatment, the students can minimize the mistake in writing correctly. This is similar to Jacobs et.al (1981) who stated that the student got mechanic as the lower score from each component of writing. So this component should have much attention.

Based on the positive effect of treatment using juxtaposing pictures in writing description, the score of the students' posttest improved. During the treatment the students were interested in learning English to improve their vocabulary and grammar ability. It can be seen from the students' enthusiasm to write description using Juxtaposing Pictures. The students' score was improved in posttest. Students' score was classified into very good, good, average, poor, and only twelve students were still poor.
Based on the result of each test, scores of posttest were greater than those in pretest. It indicates that there was an improvement of students in writing description after the treatment. This is similar to a research done by Nita Kurniawati (2009) who found that there are some strategies for the teacher in improving knowledge by using descriptive text.

Therefore, researcher concludes that the use of Juxtaposing Pictures is one of good methods that can improve the students' skill in writing description. From the discussion above, it can be concluded that the students' writing ability of the second year students of SMA N 1 ALLA academic year 2017-2018 can be improved in writing description by using juxtaposing pictures. There is a significant difference between the result of pre-test and post-test, where the mean score of pre-test (58.88)which is lower than the mean score of post-test (65.94), and t-test value of final score in writing ability (9.09) is greater than t-table (2.039).

\section{CONCLUSION}

Based on the findings of the study, it can be concluded that the use of juxtaposing pictures can improve the writing ability in writing description of the second year students of SMAN 1 Enrekang in academic year 2017-2018. There was a significant difference between the result of pre-test and post-test, where the mean score of pre-test (58.88) was lower than the mean score of post-test (65.94), and t-test value of final score in writing ability (9.09) was greater than ttable (2.039).

\section{REFERENCES}

Rezky A.N. (2009). Improving Writing Skill Using Juxtaposing Pictures. Makassar: Uin alauddin Makassar. 
Arikunto, S. (2006). Prosedur Penelitian:Suatu Pendekatan Praktek (Rev ed.). Jakarta: Rineka cipta.

Astika, G. G. (1993). Analytical assessment of foreign students' writing . RELC Journal , 24(1), 6172

Behrens, K., Rosen, L. J., \& Wesley, A. (1999).Writing and reading Across curriculum.New York: Longman.

British Council. (2007). Empowering Asia: New Paradigms in English Language Education.5th ASIA TEFL International Conference. Malaysia: MELTA.

Depdikbud. (1994). GBPP Pengajaran Bahasa Inggris SLTP. Jakarta: Direktorat Jenderal Pandidikan Pusat.

Deporter, B., Reardon. M., \& Nourie. S. S. 2000. Quantum Teaching. Bandung: Kaifa.

Feldman, R. S. (2005). Power learning: strategies for success in college and life, 2nd ed.). New York: McGraw Hill Companies Inc.

Free Dictionary.(2000). juxtaposing.google.com

Harmer, J.(1991).The practice of English Language Teaching. London: Longman.

Heaton. (1988). Writing English Language Tests. New York: Longman.

Hughes,A. (2006).Testing for language teachers, 2nd ed.).Cambridge: Cambridge University Press. Jabu, B. (2008). English Language Testing. UNM

Jacobs. (1981). ESL Composition Profile. http://eli.tamu.edu/resources/profile.html. Accessed on 16th November 2009.

Jacobs, H.l., Zinkgraf, S.A., Wormuth, D.R., Hartfiel, V.F., \& Hughey, J.B. (1981) .Testing ESL Composition: A Practical Approach . Rowley, MA: Newbury House.

Longman. (2004). Longman dictionary of American English (new ed.). England: Pearson Education Limited.

Mclead, T. W. (1983). The new Collins International Dictionary of the English Language. Singapore: Collins U.K and graham Brash.

Nordquist, R. (2009). The principle of good writing. Article http://grammar.about.com/bio/Richard.Nordquist-22176.htm. Accessed on 28th October $\underline{2009}$.

Nuraida. (2003). The Writing Skill of the Sixth Semester Students of English Department of Tarbiyah Faculty of IAIN Alauddin Mks in Free Composition.Thesis IAIN Alauddin Makassar.

Putatunda ,Rita. Descriptive Writing . Retrieved June 20,2010.from http://www.buzzle.com/authors.asp?author=11077

Rasdinayah. (2006). Increasing the writing skill of the Third years students of MADANI Islamic junior High school of Alauddin Pao-Pao gowa through Collaborative writing.Thesis UIN Alauddin Makassar.

Rahmat, A. (2004). Improving the English writing Ability of the Third year Students of MAN Kajuara Bone through Diary writing. Thesis IAIN Alauddin Makassar.

Scott, W. A., \& Treberg, L. H.Y. (1990). Teaching English to Children. New York, USA: Longman 
Straker, D. Changing Minds.from http://changingminds.org/explanations/research/analysis/ttest_table.htm

Suherni. (2008). Using Diagram to Develop the Students' Writing Ability. Thesis FBS UNM

Wishon, G. E., \& Burks, J. M. (1980). Let's write English (rev. ed.). Washington: Educational Publishing Inc.

Wright, A. (1989). Pictures for Language Learning. Cambridge: Cambridge University Press 